\title{
Pengaruh Pelaksanaan Asuhan Keperawatan Keluarga terhadap Perawatan Kesehatan Anggota Keluarga Lansia
}

\author{
Cahya Tribagus Hidayat \\ Fakultas Ilmu Kesehatan, Universitas Muhammadiyah Jember, Jember 68121, Indonesia \\ Alamat Korespondensi: J1. Karimata No. 49 Sumbersari, Kabupaten Jember, Jawa Timur \\ 68124, Kotak Pos 104 Telp. (0331) 336728 Fax. 337967 \\ Email: cahyatribagus@unmuhjember.ac.id
}

Diterima: 02 Juni 2021 | Disetujui: 27 Juni 2021

\begin{abstract}
Abstrak
Latar Belakang dan Tujuan: Keluarga mempunyai peran penting terhadap pembentukan karakter individu, keluarga dapat berfungsi dalam memenuhi segala kebutuhan anggota keluarganya. Aktivitas keluarga dalam menjalankan fungsi kesehatan keluarga tidak terlepas dari lima tugas kesehatan keluarga. Unit fungsional terkecil dalam pemberian asuhan keperawatan keluarga adalah keluarga, anggota keluarga memiliki peran penting dalam keterlibatan pemberian asuhan keperawatan keluarga khususnya pada lansia. Tujuan penelitian ini adalah mengetahui pengaruh pelaksanaan asuhan keperawatan keluarga terhadap perawatan kesehatan anggota keluarga lansia.

Metode: Desain penelitian menggunakan pra-eksperimental dengan one-group pre-post test design. Sampel dalam penelitian ini adalah keluarga yang memiliki anggota keluarga dengan lansia sejumlah 40 responden yang diambil menggunakan consecutive sampling.

Hasil: Uji statistik menggunakan $t$ test dependent dengan nilai $\alpha=0,05$. Hasil uji statistik $t$-test dependent diperoleh $p$ value 0,000 dengan $\alpha=0,05$.

Simpulan dan Implikasi: Ada pengaruh pelaksanaan asuhan keperawatan keluarga terhadap perawatan kesehatan anggota keluarga lansia. Diharapkan perawat dapat memberikan asuhan keperawatan keluarga dengan lansia sehingga keluarga bisa mandiri dan mampu melaksanakan tugas kesehatan keluarga dengan baik.
\end{abstract}

Kata Kunci: Asuhan keperawatan; Keluarga; Lansia

Sitasi: Hidayat, C.T. (2021). Pengaruh pelaksanaan asuhan keperawatan keluarga terhadap perawatan kesehatan anggota keluarga lansia. The Indonesian Journal of Health Science. 13(1), 103-109. DOI: 10.32528/ijhs.v13i1.5150

Copyright: (02021 Hidayat, C.T. This is an open-access article distributed under the terms of the Creative Commons Attribution-NonCommercial 4.0 International License, which permits unrestricted use, distribution, and reproduction in any medium, provided the original author and source are credited.

Diterbitkan Oleh: Universitas Muhammadiyah Jember

ISSN (Print): 2087-5053

ISSN (Online): 2476-9614 


\begin{abstract}
Background and Aim: The family has an important role in the formation of individual character. The most important system for individuals is the family, where the family functions to meet the needs of family members including biological, educational, psychological, sociocultural, and health functions. Family activities in carrying out family health functions cannot be separated from the five family health tasks The smallest functional unit in providing family nursing care is the family, family members have an important role in the involvement of providing family nursing care. The purpose of this study was to determine the effect of the implementation of family nursing care on the health care of elderly family members.

Methods: The research design used pre-experimental with one-group pre-post test design. The sample in this study was a family that has family members with elderly a number of 40 respondents who were taken using consecutive sampling. Results: Statistical test using $t$ test dependent with a value of $=0.05$. The results of the statistical test obtained $p$ value 0.000 with $=0.05$.

Conclusion: There is an effect of implementing family nursing care on the health care of elderly family members. It is expected that nurses can provide nursing care for families with the elderly so that families can be independent and able to carry out family health tasks well.
\end{abstract}

Keywords: Elderly; Family; Nursing care

\section{PENDAHULUAN}

Keluarga merupakan suatu sitem sosial dan kelompok kecil yang terdiri dari individu-individu yang memiliki hubungan erat satu sama lain, saling tergantung yang diorganisir dalam satu unit tunggal dalam rangka mencapai tujuan tertentu. Menurut Friedman dalam (Padila, 2012) keluarga memiliki pengaruh yang penting tehadap pembentukan identitas individu, status kesehatan dan perasaan harga diri individu (Agrina \& Zulfitri, 2012). Sistem pendukung yang vital bagi individu adalah keluarga, di mana keluarga berfungsi untuk memenuhi kebutuhan-kebutuhan anggota keluarga dengan menjalankan fungsi biologi, fungsi pendidikan, fungsi psikis, fungsi sosiokultural, serta fungsi kesehatan (Susanto, 2010). Aktivitas-aktivitas keluarga dalam menjalankan fungsi kesehatan dan kesimbangan antara anggota keluarga tidak terlepas dari lima tugas dalam perawatan kesehatan keluarga yaitu: mampu mengenal masalah kesehatannya, mampu mengambil keputusan yang tepat untuk mengatasi kesehatannya, mampu melakukan tindakan keperawatan untuk anggota keluarga yang memerlukan bantuan keperawatan, mampu memodifikasi lingkungan sehingga menunjang upaya peningkatan kesehatan, mampu memanfaatkan sarana pelayanan kesehatan yang ada (Friedman \& Marilyn, 2010)

Sebuah penelitian yang dilakukan oleh Friedman 2014 di Amerika Serikat, mengenai efek kunjungan rumah dan intervensi perawat dibanding dengan aktivitas biasa, pada pemenuhan Activity Daily Life (ADL) dengan jumlah 499 lansia, bahwa terdapat penurunan ketergantungan dalam pemenuhan ADL setelah dilakukan kunjungan rumah dan 
intervensi perawat pada lansia. Lanjut usia adalah tahap akhir dari tahap perkembangan keluarga, pada tahapan ini lansia sudah mengalami kemunduran fungsi fisiologis organ tubuhnya (Maryam et al., 2008).

Semakin lanjut usia seseorang maka kemampuan fisik, ekonomi, dan kesibukan sosialnya akan berkurang. Pengaruh proses menua akan mengancam kemandirian dan kualitas hidup (Baroroh \& Irafayani, 2015). Hasil studi pendahuluan yang dilakukan di Puskesmas Kaliwates Kabupaten Jember didapatkan angka kunjungan dengan jumlah keluarga yang mendapatkan pelayanan kesehatan sebanyak 321, jumlah anggota keluarga yang mendapatkan pelayanan kesehatan sebanyak 436, jumlah perawatan penanganan risiko tinggi sebanyak 247. Selain itu di Puskesmas Kaliwates Kabupaten Jember didapatkan angka sepuluh penyakit terbanyak dari kunjungan lansia di Puskesmas pada tahun 2019 dengan penyakit: Hipertensi 5899 kasus, Diabetes Mellitus 4321 kasus, gastritis 1564 kasus, gangguan nefrotik 1713 kasus, penyakit kulit alergi 1150 kauss, penyakit jantung iskemik 458 kasus.

Tingginya angka kesakitan lansia dan angka harapan hidup lansia, secara langsung dapat meningkatkan ketergantungan pemenuhan kebutuhan lansia (Yusselda \& Wardani, 2016). Keluarga menjadi faktor utama dalam upaya mencapai kesehatan masyarakat secara optimal karena memiliki keterkaitan dengan masalah kesehatan, memiliki fungsi utama dalam masyarakat dan lembaga yang menyangkut kehidupan masyarakat. Peran keluarga sebagai kelompok dapat melakukan aktivitas pencegahan, memelihara, menimbulkan, memperbaiki ataupun mengabaikan masalah kesehatan yang ada di dalam kelompok keluarga. Keluarga berperan sebagai pengambil keputusan dalam memelihara kesehatan anggota keluarganya, yang berarti keluarga menjadi faktor utama dalam menentukan kondisi sehat dan sakitnya anggota keluarganya, yang akan berdampak pada munculnya berbagai masalah kesehatan anggota keluarga. Keluarga menjadi unit terdepan dalam memberikan pelayanan kesehatan. Apabila setiap keluarga sehat, akan tercipta komunitas yang sehat pula. Apabila terdapat salah satu anggota keluarga yang sakit maka akan mempengaruhi sistem keluarga, komunitas setempat bahkan komunitas secara luas. Oleh sebab itu kesehatan dan kemandirian keluarga merupakan kunci utama pembangunan kesehatan masyarakat (Ekasari, 2008).

Unit fungsional terkecil dalam pemberian asuhan keperawatan keluarga adalah keluarga, peran dan partisipasi keluarga sangat mempengaruhi hasil dari asuhan keperawatan keluarga lansia tersebut (Badriyah, 2013). Selain keluarga, perawat juga memiliki peran penting yakni sebagai pendidik, koordinator atau penghubung, advokat atau pelindung, pemberi pelayanan langsung, konselor, dan modifikator lingkungan.

Pelaksanaan pelayanan keperawatan keluarga selaras dengan tiga tingkat pencegahan. Tingkat pertama (promotion dan primary prevention), pencegahan tingkat kedua (secondary prevention), maupun pencegahan tingkat ketiga (tertiary prevention). Setiap pencegahan melibatkan keluarga sebagai mitra kerja dalam perencanaan, pelaksanaan, dan evaluasi dari setiap pelayanan keperawatan yang diberikan pada keluarga (Depkes RI, 2006). 


\begin{abstract}
Beberapa penelitian hanya berfokus pada peningkatan peran keluarga dan upaya melibatkan keluarga. Sedangkan evaluasi dari tindakan pelaksanaan asuhan keperawatan keluarga belum pernah dilakukan. Berdasarkan hal tersebut, maka tujuan penelitian ini adalah mengetahui efektivitas pelaksanaan asuhan keperawatan keluarga terhadap perawatan kesehatan anggota keluarga lansia.
\end{abstract}

\section{METODE PENELITIAN}

Penelitian menggunakan jenis kuantitatif dengan pendekatan praeksperimental dengan metode onegroup pre-post test design. Sampel dalam penelitian ini adalah keluarga dengan lansia sejumlah 40 responden yang diambil menggunakan consecutive sampling. Consecutive Sampling yaitu semua subyek yang datang dan memenuhi kriteria pemilihan dimasukkan dalam penelitian sampai jumlah subyek yang diperlukan terpenuhi (Notoatmodjo, 2010).

Alat pengumpulan data menggunakan kuisioner tentang pelaksanaan asuhan keperawatan keluarga. Kuesioner ini terdiri dari 8 item pertanyaan utama dalam asuhan keperawatan keluarga dan telah terstandarisai sesuai dengan teori Friedman. Kuisioner digunakan sebelum dan sesudah diberikannya asuhan keperawatan keluarga terhadap perawatan kesehatan pada keluarga lansia.

Data yang terkumpul kemudian ditabulasi dan dianalisis menggunakan uji statistik (uji $T$ dependen) yang bertujuan untuk mengetahui apakah ada pengaruh asuhan keperawatan keluarga pada terhadap perawatan kesehatan pada keluarga lansia.

\section{HASIL PENELITIAN}

Karakteristik responden berdasarkan Tabel 1 diketahui bahwa jenis kelamin didominasi oleh perempuan yaitu sebanyak 26 orang (65\%) dan mayoritas usia 61-70 tahun yaitu sebanyak 20 orang (50\%).

Tabel 1. Karakteristik Responden $(\mathrm{n}=40)$

\begin{tabular}{ccc}
\hline Karakteristik & F & Presentase \\
\hline Jenis Kelamin & & \\
Laki-laki & 14 & 35 \\
Perempuan & 26 & 65 \\
Usia & & \\
50-60 Tahun & 14 & 35 \\
61-70 Tahun & 20 & 50 \\
$>$ 70 Tahun & 6 & 15 \\
\hline
\end{tabular}

Tabel 2 menunjukkan bahwa sebelum diberikan asuhan keperawatan keluarga tentang perawatan kesehatan bagi lansia sebagian besar berada pada kategori cukup yaitu 20 orang (50\%). Sedangkan setelah diberikan asuhan keperawatan keluarga tentang perawatan kesehatan bagi lansia sebagian besar berada pada kategori baik yaitu 26 orang $(65 \%)$.

Tabel 2. Data responden sebelum dan sesudah diberikan asuhan keperawatan keluarga tentang perawatan kesehatan bagi lansia

\begin{tabular}{ccc}
\hline $\begin{array}{c}\text { Perawatan } \\
\text { kesehatan }\end{array}$ & F & Presentase (\%) \\
\hline \multicolumn{3}{c}{ Sebelum } \\
\hline Kurang & 12 & 30 \\
Cukup & 20 & 50 \\
Baik & 8 & 20 \\
\hline \multicolumn{3}{c}{ Sesudah Intervensi } \\
\hline Kurang & 4 & 10 \\
Cukup & 10 & 25 \\
Baik & 26 & 65 \\
\hline
\end{tabular}

Berdasarkan tabel 3 hasil uji statistik t-test dependent diperoleh $p$ value 0,000 dengan $\alpha=0,05$. Hal ini menunjukkan bahwa terdapat pengaruh 
yang signifikan pemberian asuhan keperawatan keluarga terhadap perawatan kesehatan bagi lansia.

Tabel 3. Analisis statistik perbedaan perawatan kesehatan lansia sebelum dan sesudah asuhan keperawatan

\begin{tabular}{lllc}
\hline Variabel & Mean & P value & $\mathbf{N}$ \\
\hline Pre test & 2,26 & 0,000 & 40 \\
Post test & 3,68 & & \\
\hline
\end{tabular}

\section{PEMBAHASAN}

$\begin{array}{lrr}\text { Hasil } & \text { sebelum diberikannya } \\ \text { asuhan keperawatan } & \text { keluarga }\end{array}$ menunjukkan bahwa pemahaman keluarga tentang perawatan kesehatan bagi lansia sebagian besar berada pada kategori cukup. Hal ini disebabkan karena kurangnya pengetahuan keluarga tentang berbagai masalah kesehatan atau penyakit yang dialami oleh semua anggoota keluarga. Sejalan dengan penelitian (Peter \& Penzel, 2020) diketahui masih kurangnya pengetahuan dan kemampuan keluarga dalam melakukan perawatan kesehatan keluarga untuk mencegah dan mengatasi berbagai masalah kesehatan di dalam keluarga. Rendahnya pengetahuan keluarga tersebut disebabkan oleh berbagai faktor, diantaranya: tingkat pendidikan kepala keluarga yang masih rendah, status sosial ekonomi keluarga yang bervariasi, serta keterbatasan tenaga petugas kesehatan dari Puskesmas untuk membina keluarga diwilayah kerjanya. Menurut (Notoatmodjo, 2007), banyak faktor yang mempengaruhi perilaku kesehatan, diantaranya adalah: faktor internal (pengetahuan, status sosial ekonomi), dan faktor eksternal (dukungan sosial khususnya dari petugas kesehatan).

$\begin{array}{ccr}\text { Hasil } & \text { setelah } & \text { diberikannya } \\ \text { asuhan keperawatan } & \text { keluarga } \\ \text { menunjukkan bahwa } & \text { pemahaman }\end{array}$

keluarga tentang perawatan kesehatan bagi lansia sebagian besar berada padakategori baik. Berdasarkan hasil uji statistik diketahui ada pengaruh yang signifikan antara asuhan keperawatan keluarga tentang perawatan kesehatan bagi lansia. Sesuai dengan penelitian (Baroroh \& Irafayani, 2015) bahwa asuhan keperawatan efektif meningkatkan tingkat kemandirian keluarga. Menurut (Friedman, 2003), fungsi perawatan kesehatan keluarga bisa tercapai dilihat dari kemampuan keluarga memahami dan melaksanakan lima tugas kesehatan keluarga (Ahsan et al., 2018). Hal ini sangat tergantung dari peran perawat dalam memberikan asuhan keperawatan pada keluarga, sehingga diharapkan keluarga mendapatkan upaya pembinaan dan bimbingan dalam menjalankan lima fungsi perawatan kesehatan keluarga (Guriti \& Ismarwati, 2020).

Upaya pembinaan dan bimbingan kepada keluarga sangat mempengaruhi tercapainya kemandirian keluarga dalam mengatasi berbagai masalah kesehatan di keluarga (Karlina \& Kora, 2020). Hal ini disebabkan karena asuhan keperawatan keluarga merupakan rangkaian kegiatan transfer ilmu dan kemampuan keluarga mengatasi masalah kesehatan yang ada dengan menggunakan berbagai strategi guna terjadinya perubahan perilaku ke arah yang lebih baik (Permana \& Tarigan, n.d.). Strategi atau metode yang digunakan meliputi pendidikan kesehatan menggunakan verbal, psikomotor (praktik) dan afektif untuk melihat sejauh mana kepatuhan keluarga melakukan kegiatan mengatasi masalah kesehatan yang ada di keluarga.

Strategi perubahan perilaku adalah dengan memberikan informasi tentang 
cara menghindari penyakit dan meningkatkan pengetahuan masyarakat. Selanjutnya dengan pengetahuan tersebut dapat menimbulkan kesadaran di antara masyarakat untuk berperilaku sesuai dengan pengetahuan yang dimiliki. Penelitian (Basuki, 2006) memperlihatkan bahwa metode pendidikan kesehatan mempunyai hubungan yang bermakna dalam peningkatan pengetahuan. Penelitian Basuki ini sesuai dengan hasil pada penelitian ini, di mana rata-rata kemandirian keluarga mengatasi masalah kesehatan sesudah diberikan asuhan keperawatan keluarga (2,26 menjadi 3,68). Rata-rata kemampuan dalam mengatasi masalah kesehatan di keluarga berada pada tingkat kategori baik setelah dilakukan pemberian asuhan keperawatan keluarga.

\section{SIMPULAN}

Pemberian asuhan keperawatan keluarga efektif dalam meningkatkan perawatan kesehatan lansia.

\section{SARAN}

Diharapkan penelitian ini dapat menjadikan asuhan keperawatan keluarga sebagai referensi bagi masyarakat untuk memberikan perawatan keluarga, sehingga keluarga dapat melakukan tugas kesehatan keluarga dengan baik. penelitian ini dapat menjadi masukan dan digunakan dalam melakukan intervensi keperawatan keluarga untuk penanganan permasalahan masyarakat yang mengalami masalah kesehatan didalam keluarga.

\section{DAFTAR PUSTAKA}

Agrina, A., \& Zulfitri, R. (2012). Efektifitas asuhan keperawatan keluarga terhadap tingkat kemandirian keluarga mengatasi masalah kesehatan di keluarga. Sorot, $\quad 7(2), \quad 81$. https://doi.org/10.31258/sorot.7.2. 2003

Ahsan, A., Kumboyono, K., \& Faizah, M. N. (2018). Hubungan pelaksanaan tugas keluarga dalam kesehatan dengan kemandirian lansia dalam pemenuhan aktivitas sehari-hari. Jurnal Kesehatan Mesencephalon, 4(1). https://doi.org/10.36053/mesence phalon.v4i1.69

Badriyah, M. (2013). Manajemen sumber daya manusia. CV Pustaka Setia.

Baroroh, D. B., \& Irafayani, N. (2015). Peran keluarga sebagai care giver terhadap pengelolaan aktifitas pada lansia dengan pendekatan NIC (Nursing Intervention Classification) Dan NOC (Nursing Outcome Classification). Jurnal Keperawatan, 3(2), 141151.

Basuki. (2006). Efektifitas metoda penyuluhan dalam peningkatan pengetahuan tentang hygiene pada murid SD KecamatanSeberida Kabupaten Indragiri Hulu. Tesis. Universitas Sumatra Utara.

Depkes RI. (2006). Pedoman penyelenggaraan dan prosedur rekam medis rumah sakit di Indonesia. Depkes RI.

Ekasari, M. F. (2008). Keperawatan komunitas. Trans Info Medika.

Friedman. (2003). Family nursing: research, theory \& practice, 4th ed. Appleton and Lange.

Friedman, \& Marilyn, M. (2010). Keperawatan keluarga teori dan praktik. terjemahan. Jakarta: EGC

Guriti, G., \& Ismarwati, I. (2020). Peran keluarga pada perawatan lansia. Jurnal Keperawatan, 
12(2), 241-244.

Karlina, L., \& Kora, F. T. (2020). Hubungan peran perawat sebagai care giver dengan tingkat kecemasan pada lansia correlation between the role of nurse as a care giver with level of anxiety in the elderly. Jurnal Kesehatan Samodra Ilmu, 11(1), 104-113.

Maryam, R. S., Ekasari, M. F., Rosidawati, Jubaedi, A., \& Batubara, I. (2008). Mengenal usia lanjut dan perawatannya. Salemba Medika.

Notoatmodjo, S. (2010). Metodologi penelitian kesehatan. Rineka Cipta.

Padila. (2012). Buku ajar keperawatan medikal bedah. Jakarta: EGC

Permana, A., \& Tarigan, S. (n.d.). Proses Keperawatan dalam Meningkatkan Kesehatan Lansia

Peter, H., \& Penzel, T. (2020).
Hubungan pengetahuan kesehatan terhadap peran keluarga dalam perawatan lansia dengan gangguan mobilitas fisik di ruang perawatan RSUD Pakuhaji Kabupaten Tangerang. 3(1), 1-1. https://doi.org/10.1007/978-3642-54672-3_415-1

Susanto, T. (2010). Pengaruh Terapi keperawatan keluarga terhadap tingkat kemadirian keluarga dengan permasalahan kesehatan reproduksi pada remaja di Kelurahan Ratujaya Kecamatan Pancoran Mas Kota Depok. Jurnal Keperawatan, 1(2), 9. file:///C:/Users/USER/Downloads 11593-3845-1-SM (1).pdf

Yusselda, M., \& Wardani, I. Y. (2016). Dampak dukungan keluarga terhadap kualitas hidup lansia. Jurnal Keperawatan, 8(1), 9-13. 